\title{
Viral basophilic inclusions in the digestive gland of razor clams Ensis arcuatus (Pharidae) in Galicia (NW Spain)
}

\author{
M. Ruiz ${ }^{1}$, S. Darriba ${ }^{2}$, R. Rodríguez ${ }^{3}$, D. Iglesias ${ }^{1}$, R. Lee ${ }^{4}$, C. López ${ }^{1, *}$ \\ ${ }^{1}$ Centro de Investigacións Mariñas (CIMA), PO Box 36620, Vilanova de Arousa, Pontevedra, Spain \\ ${ }^{2}$ Instituto Tecnolóxico para o Control do Medio Mariño de Galicia (INTECMAR), PO Box 36611, Vilagarcía de Arousa, \\ Pontevedra, Spain \\ ${ }^{3}$ Estación de Ciencias Mariñas de Toralla (ECIMAT), PO Box 36331, Vigo, Pontevedra, Spain \\ ${ }^{4}$ Consello Regulador do Mexillón de Galicia, PO Box 36600, Vilagarcía de Arousa, Pontevedra, Spain
}

\begin{abstract}
During a histological survey of razor clam Ensis arcuatus (Jeffreys, 1865) from Galicia (NW Spain), basophilic inclusion bodies were observed in epithelial cells of the digestive gland. Transmission electron microscopy revealed the intranuclear position of these inclusions containing viral particles with icosahedral symmetry. Size and symmetry of these unenveloped virus particles suggest similarities to the families Papillomaviridae and Polyomaviridae which have been described as causing a viral gametocytic hypertrophy in oysters Crassostrea virginica and C. gigas. This is the first report of viral particles in E. arcuatus.
\end{abstract}

KEY WORDS: Ensis arcuatus - Histopathology · Ultrastructure - Basophilic inclusion bodies · Viral particles

\section{INTRODUCTION}

Viruses that have been described as affecting bivalves belong to the families Papillomaviridae, Polyomaviridae, Malacoherpesviridae, Togaviridae, Retroviridae, Reoviridae, Birnaviridae, Iridoviridae, Picornaviridae, and Baculoviridae (Elston 1997, Chang et al. 2002, Renault \& Novoa 2004, Davison et al. 2009). A viral gametocytic hypertrophy (VGH) provoked by intranuclear basophilic inclusions in gametes was detected in oysters (Farley 1976, McGladdery \& Stephenson 1994, Winstead \& Courtney 2003, Choi et al. 2004, Garcia et al. 2006, Cheslett et al. 2009, Meyers et al. 2009). Transmission electron microscopy (TEM), performed by these authors, demonstrated virus-like particles probably belonging to Papillomaviridae and Polyomaviridae (referred to in previous literature as Papovaviridae). Prevalence and intensity were low, and no adverse effect was reported on oyster health. However, mortalities of bivalves associated with the presence of viral particles have been reported (Elston 1997, Renault \& Novoa 2004, Maeno et al. 2006).

Basophilic inclusion bodies in epithelial cells of the digestive gland, resembling intranuclear inclusions of the VGH in oysters, were found in histological sections during a pathological study of razor clams Ensis arcuatus (Solenidae) from Galicia, Spain (Darriba et al. 2010). The prevalence and intensity of these inclusions were usually low, and no adverse effects were reported in the razor clams. The objective of the present note was to continue with the study of the basophilic inclusion bodies in E. arcuatus from Galicia, reported by Darriba et al. (2010). 


\section{MATERIALS AND METHODS}

Further analyses were performed on the histological samples used in the study by Darriba et al. (2010). Previously stained (with Harris' hematoxylin and eosin, H\&E) slides were re-examined, and new histological sections of the specimens affected by inclusion bodies were made and stained using Feulgen picromethyl blue (Farley 1969). A sample showing high intensity of inclusion bodies in epithelium cells of the digestive gland of Ensis arcuatus was selected to perform an ultrastructural analysis. The portion of tissue containing the inclusions was removed from the paraffin block with a scalpel. Paraffin was removed by several rinses in xylene with agitation. Tissue was placed in $2.5 \%$ glutaraldehyde, postfixed in $2 \% \mathrm{OsO}_{4}$, and embedded in Epon. Ultra-thin sections were stained with uranyl acetate and lead citrate and examined in a JEOL JEM 1010 transmission electron microscope (TEM) at $80 \mathrm{kV}$.

\section{RESULTS AND DISCUSSION}

The unidentified basophilic inclusions observed, using light microscopy and H\&E stain, in epithelial cells of the digestive gland had chromophilic margins (Fig. 1). These inclusions showed a Feulgen-positive reaction, indicating the presence of DNA. TEM examination confirmed the intranuclear position of the basophilic inclusions and the presence of viral particles inside of the inclusions (Fig. 2). The virions were unenveloped, with a rounded appearance suggesting icosahedral symmetry (Fig. 3). The size of virions was 38.27 $\pm 3.93 \mathrm{~nm}$ in diameter (mean $\pm \mathrm{SD}, \mathrm{n}=30$ ). Both empty and full capsids could be observed (Fig. 3). The chro-

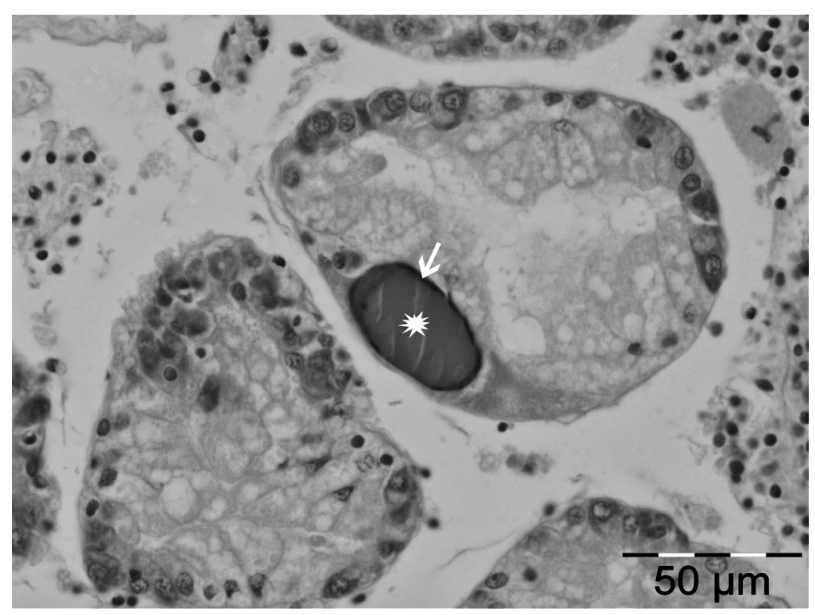

Fig. 1. Ensis arcuatus. Light micrograph showing basophilic inclusion body (asterisk) in the epithelial cell of the digestive gland with chromophilic margin (arrow). Hematoxylin and eosin stained

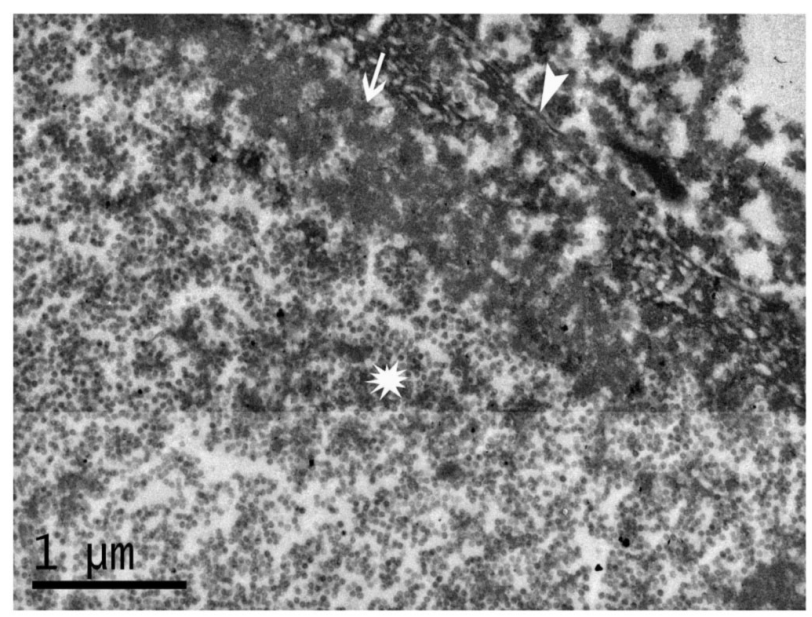

Fig. 2. Ensis arcuatus. Ultrathin section detail of an intranuclear inclusion, showing viral particles (asterisk), nuclear membrane (arrowhead) and peripheral chromatin (arrow)

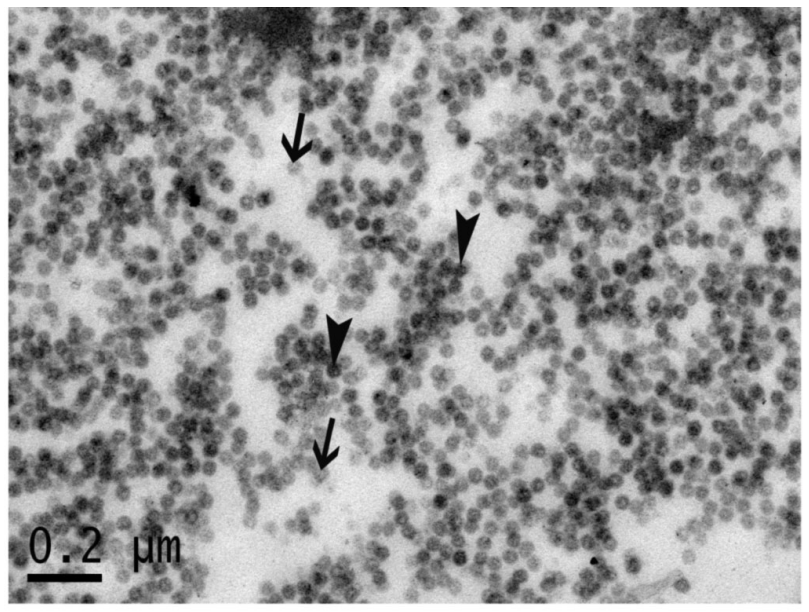

Fig. 3. Ensis arcuatus. Ultrathin section showing icosahedral symmetry of the viral particles. Presence of empty (arrows) and full capsids (arrowheads)

mophilic margins, viewed by light microscopy, were identified as peripherally displaced chromatin (Fig. 2). The intranuclear location of the basophilic inclusions of Ensis arcuatus, high hypertrophy of the infected cells, and the size and symmetry of unenveloped virions are in concordance with the description of the virus causing VGH in Crassostrea virginica (Farley 1976, McGladdery \& Stephenson 1994, Winstead \& Courtney 2003) and C. gigas (Choi et al. 2004, Garcia et al. 2006, Cheslett et al. 2009, Meyers et al. 2009). With regard to the size and symmetry of the unenveloped virions, all the latter authors suggested similarities to the families Papillomaviridae and Polyomaviridae. Papovavirus-like infection affecting labial palps of Pinctada maxima was reported by Norton et al. (1993). In this case, the inclusions observed by light 
microscopy were eosinophilic and usually separated from the peripheral nuclear chromatin by a clear zone, in contrast to the basophilic affinity observed in oysters and razor clams.

Pass et al. (1988) described intranuclear basophilic inclusions in the digestive gland of Pinctada maxima, but infected cells showed slight hypertrophy, and virions (about $38 \mathrm{~nm}$ in diameter) were inside of an electron-dense amorphous matrix, unlike the viral inclusions of Ensis arcuatus in the present study, and of oysters affected by VGH (Farley 1976, McGladdery \& Stephenson 1994, Winstead \& Courtney 2003, Choi et al. 2004, Garcia et al. 2006, Cheslett et al. 2009, Meyers et al. 2009).

Intracytoplasmatic and unenveloped viruses were detected in the digestive gland of Perna canaliculus, Pecten novaezelandiae, and Paphies ventricosum (Jones et al. 1996, Hine \& Wesney 1997) and in gill and kidney of Atrina pectinata (Maeno et al. 2006). The presence of these intracytoplasmatic viruses was associated with mortalities. In the case of VGH, absence or limited impact at population levels were reported; however, Garcia et al. (2006) commented that the virus may affect the viability of oyster gametes. In the present study, the low prevalence and intensity detected, and the absence of a host inflammatory response, suggest that these inclusions would not be a serious problem to razor clam populations.

This is the first report of viral particles in Ensis arcuatus. Based on ultrastructural morphological characteristics, virions cannot be assigned with certainty to the families Papillomaviridae or Polyomaviridae. The absence of immunoglobulin production in mollusks, together with the lack of molluskan cell lines, make virus isolation and identification difficult. The further development of molecular techniques will be an important tool in the study of viruses.

Acknowledgements. We thank J. Méndez and I. Pazos for ultrastructural techniques (CACTI- Vigo University) and A. González, M. I. Meléndez, E. Penas, M. Miranda and I. Santamaría for technical assistance.

\section{LITERATURE CITED}

Chang JC, Huh M, Oh M, Sugawara Y (2002) Baculoviruslike particles in epithelial cell of digestive diverticula of the scallop, Patinopecten yessoensis. J Shellfish Res 21:109-112

Editorial responsibility: Eugene Burreson, Gloucester Point, Virginia, USA
Cheslett D, McKiernan F, Hickey C, Collins E (2009) Viral gametocytic hypertrophy of the Pacific oyster Crassostrea gigas in Ireland. Dis Aquat Org 83:181-185

Choi DL, Lee NS, Choi HJ, Park MA, MacGladdery SE, Park MS (2004) Viral gametocytic hypertrophy caused by a papova-like virus infection in the Pacific oyster Crassostrea gigas in Korea. Dis Aquat Org 59:205-209

Darriba S, Iglesias D, Ruiz M, Rodriguez R, López C (2010) Histopathological survey of symbionts and other conditions in razor clam Ensis arcuatus (Jeffreys, 1865) (Pharidae) of the coast of Galicia (NW Spain). J Invertebr Pathol 104:23-30

Davison AJ, Eberle R, Ehlers B, Hayward GS and others (2009) The order Herpesvirales. Arch Virol 154:171-177

Elston RA (1997) Special topic review: bivalve mollusc viruses. World J Microbiol Biotechnol 13:393-403

Farley CA (1969) Probable neoplastic disease of the hematopoietic system in oysters, Crassostrea virginica and Crassostrea gigas. In: Dawe CJ, Harshbarger JC (eds) Neoplasms and related disorders of invertebrate and lower vertebrate animals. Natl Cancer Inst Monogr 31:541-555

- Farley CA (1976) Ultrastructural observations on epizootic neoplasia and lytic virus infection in bivalve molluscs. Prog Exp Tumor Res 20:283-294

Garcia C, Robert M, Arzul I, Chollet B and others (2006) Viral gametocytic hypertrophy of Crassostrea gigas in France: from occasional records to disease emergence? Dis Aquat Org 70:193-199

Hine PM, Wesney B (1997) Virus-like particles associated with cytopathology in the digestive gland epithelium of scallops Pecten novaezelandiae and toheroa Paphies ventricosum. Dis Aquat Org 29:197-204

> Jones JB, Scotti PD, Dearing SC, Wesney B (1996) Virus-like particles associated with marine mussel mortalities in New Zealand. Dis Aquat Org 25:143-149

Maeno Y, Yurimoto T, Nasu H, Ito S and others (2006) Viruslike particles associated with mass mortalities of the pen shell Atrina pectinata in Japan. Dis Aquat Org 71:169-173

McGladdery SE, Stephenson MF (1994) A viral infection of the gonads of eastern oyster (Crassostrea virginica) from Atlantic Canada. Bull Aquac Assoc Can 94:84-86

> Meyers TR, Burton T, Evans W, Starkey N (2009) Detection of viruses and virus-like particles in four species of wild and farmed bivalve molluscs in Alaska, USA, from 1987 to 2009. Dis Aquat Org 88:1-12

> Norton JH, Shepherd MA, Prior HC (1993) Papova-like virus infection of the golden-lipped pearl oyster, Pinctada maxima, from the Torres Strait, Australia. J Invertebr Pathol 62:198-200

Pass DA, Perkins FP, Dybdahl R (1988) Viruslike particles in the digestive gland of the pearl oyster (Pinctada maxima). J Invertebr Pathol 51:166-167

> Renault T, Novoa B (2004) Viruses infecting bivalve molluscs. Aquat Living Resour 17:397-409

Winstead JT, Courtney LA (2003) Ovacystis-like condition in the eastern oyster Crassostrea virginica from the northeastern Gulf of Mexico. Dis Aquat Org 53:89-90

Submitted: October 21, 2010; Accepted: January 5, 2011

Proofs received from author(s): March 30, 2011 